\title{
Multiplex PCR of Some Antibiotic Resistance Genes of Methicillin Resistant Staphylococcus Aureus (MRSA) Isolated from Infected Cat Fish (Clarias garipeneaus).
}

\author{
Khafagy, A. R. ${ }^{1}$; El-Gamal, R. M. ${ }^{2}$; Hala F. A. ${ }^{2}$ and Samaa A.M ${ }^{1}$ \\ 1. Faculty of Vet. Medicine, Suez Canal University. 2. Central laboratory \\ for Aquaculture Research, Agriculture Research Center, Egypt.
}

\begin{abstract}
This study was designed to detect some antibiotic resistance genes of S.aureus by using PCR. A total of 150 Cat fish (Clarias garipeneaus) with a body weight ranged from $200-250 \mathrm{~g}$. suffered from ulcerated skin and erosion. S. aureus were isolated in percent of $100 \%$ from infected fish by using Baird parker as selective media. By using multiplex PCR for investigation some antibiotic resistant genes, as erm A gen, aac (6)-aph (2) genes, van A gen and mec A gene. All isolated $S$. aureus were sensitive to Amikacin, Amoxicillin, Ampicillin and Ciprofloxacin while resistant to Gentamicin, Methicillin and Neomycin.
\end{abstract}

\section{1-introduction}

Fish and fishery products could be the major source and acts as a vehicles for many important species of food poising bacteria, which include in addition to Salmonella, Staphylococcus, Cl. botulinum, the so-called nonspecific group of microorganisms such as E. coli, Proteus spp., Enterocerus fecalis, $C l$. perefringnes and $B$. cereus (Lotfi, et al.,1972 and Roberts, 2001). In spite of Staphylococci are not a part of the normal part of fish microflora (Herrero et al., 1999), Staphylococcus spp. May reach aquatic environments through fecal contamination and it has been isolated from fresh and brackish water fish culture pond in many countries.
S. aureus has been reported as the third major causative agent of food born illness by fish and fish products in the European Union (EFSA, 2010).

Methicillin-resistant S.aureus (MRSA) are being increasingly found outside clinical settings (Popovich et al., 2007, Ribeiro et al., 2007, Stankovic et al., 2007). MRSA have thus been found in food animals (Lee, 2003) and in fishery products recently (Beleneva, 2011). Although there is currently no evidence that eating food contaminated with MRSA may lead to an increased risk of humans becoming healthy carriers or infected with this bacterium (EFSA, 2010). 
So, for this reason, discussed molecular studies on Staphylococci infection in fresh water fish.

\section{2-Material and methods}

\section{1-Sample:-}

A total of 150 Cat fish (Clarias garipeneaus) with a body weight ranged from 200 - 250g suffered from ulcerated skin, erosions and ulcers were collected from Sewages canal (Bahr EL baker) in Sharkia Governorate and fish marked in Abbo- Hamad sharkia, in summer season in 2016.

2- Clinical \& post mortem examination of fish:-

Fish were examined clinically for any abnormal lesions according to Noga (1996) and Austin and Austin (2007), where the most common clinical signs were external hemorrhage and ulcer. Fish showed abscess formation on skin, loss skin and may extend to tail and part from fins.fig.(1)

Post mortem examination was done according to the methods described by Noga (1996) and Austin and Austin (2007).

3-Bacteriological examination of samples:-

The isolation and identification of Staphylococcus infection was carried out using standard methods of USFDA (BAM, 2001).

1-Collected samples(gills, ulcers, liver, kidney and intestine) table(1). were cultivated on Brain heart infusion broth at $37{ }^{0} \mathrm{C}$ for $24 \mathrm{hrs}$. one $\mathrm{ml}$ from each tube was spread over a dry surface of BP agar plate. All plates were incubated at $37^{\circ} \mathrm{C}$ for 24-72hrs and examined daily for bacterial growth.

2-The suspected colonies were examined for their colonial character, hemolytic activity on 5\% Sheep blood agar, microscopical examination and biochemical character according to (Quinn et al.,1994)

4-Antibiotic susceptibility testing by disc diffusion method.

The susceptibility to antibiotic was tested according to the procedures of NCCLS 2007 using disk diffusion technique. The susceptibility of the strain was determined according to inhibition zone diameter.

\section{5-DNA Extraction using QIA} amp kit

After overnight culture on nutrient agar plates, one or two colonies were suspended in $20 \mathrm{ml}$ of sterile distilled water, and the suspension was then heated at $100^{\circ} \mathrm{C}$ for 20 minutes. Accurately, 50-200 $\mu 1$ of the culture were placed in Eppendorf tube and the steps were carried out according to (Shah et al., 2009)

\section{6- PCR Amplification for MRSA gene (Pournajafet al., 2014):}

The amplification was performed on a Thermal Cycler (Master cycler, Eppendorf, Hamburg, Germany). The genomic DNA was amplified by PCR as a volume of $1 \mu \mathrm{L}(0.5$ $\mu \mathrm{g})$ in a final volume of $25 \mu \mathrm{L}$ PCR mixture containing $10 \mu \mathrm{L}$ of 2xMaster Mix, including $1 \times \mathrm{PCR}$ buffer, $1.5 \mathrm{mmol} / \mathrm{L} \mathrm{MgCl}_{2}, 0.15$ $\mathrm{mmol} / \mathrm{L} \quad \mathrm{dNTP}$, and 1.25 
IU Taq DNA polymerase, $0.7 \mu \mathrm{L}$ of $0.8 \mu \mathrm{mol} / \mathrm{L}$ each primer and $12.6 \mu \mathrm{L}$ of sterile distilled water. The thermal cycling protocol for PCR was comprised $95{ }^{\circ} \mathrm{C}$ for $3 \mathrm{~min}$, followed by 33 cycles of $94{ }^{\circ} \mathrm{C}$ for $1 \mathrm{~min}, 53{ }^{\circ} \mathrm{C}$ for $30 \mathrm{~s}$ and $72{ }^{\circ} \mathrm{C}$ for $1 \mathrm{~min}$, with a final extension at 72 ${ }^{\circ} \mathrm{C}$ for 6 min.

The PCR products were electrophoresed in $2 \%$ of agarose gel electrophoresis stained with ethidium bromide and visualized on UV transilluminator. A 100 bp plus DNA Ladder (Qiagen, Germany, $\mathrm{GmbH}$ ) was used to determine the fragment sizes.

7- PCR amplification for some antibiotic resistance genes as erm A gen , aac (6)-aph (2) genes and van A of S.aureus (Perez et al., 2001):

The multiplex PCR was performed in a total volume of $25 \mu \mathrm{L}$ containing $80 \mathrm{mM} \mathrm{MgCl}_{2}$, PCR buffer, $3.5 \mathrm{mM}$ DNTP mix (Fermentas), 14L (10 p.mol)of each of primer and 1 unit of Taq polymerase with $1 \mu \mathrm{l}$ of bacterial suspension.

\section{3-Result and discussion:-}

In the present study, as showen in table (1) 430/750 isolates from fresh water Cat fish samples (Clarias garipeneaus) were identified as $S$. aureus by colonical characters, microscopical examination and biochemical tests according to Quinn et al. (1994). In regarded to total prevalence of S.aureus in infected fishes, the present study recorded that $100 \%$ of infected fish were positive for Staphylococcal infection, these results go in barrel with Haifaa (2014) who recorded $100 \%$ from isolates (Carp, Cat fishes)were identified as Staphylococcal spp. But these results were relatively higher than those recorded by Noha (2015), who reported that $46.6 \%$ of infected Cat fishes were positive for Staphylococcal infection. Narges et al. (2013) who recorded that, Staphylococcus aureus were isolated in $37.2 \%$ from 35 samples of schizothorax Zarudnyi. Bujjamma and Padmavath (2015), who reported high prevalence of Staphylococcus aureus (24.47\%) in fishes of Guntur market. Daniel et al. (2010) recorded that, high prevalence of Staphylococcus aureus were isolated from retail outlets in Glaicia. But Vieira et al. (2001) isolated Staphylococcus aureus in percent of $30 \%$ from fresh fish. Eklund et al. (2004) isolated Staphylococcus aureus in percent of $20 \%$ from fresh fish and fish fillets (Cynoscion leiarchus). Disagreed with Athanassopoulou et al. (1999). who reported that the total prevalence of Staphylococcus epidermidis among diseased Puntazzo in marine aquaculture systems in Greece was $10 \%$. The incidence of Staphylococcus aureus reported in the present study was relatively higher than those of freshwater fishes reported by $\boldsymbol{A l i}$ (2014) and El-olemy et al. (2014). The high incidence of 
Staphylococcus aureus in the examined samples could indicate unhygienic conditions because the product contamination could be the results of a combination of improper handling, improper storage and cross contamination (Simon and Sanjev, 2007).

The present result showed that, Staphylococcus aureus isolated in percent of $100 \%$ from skin and gills, $40 \%$ from liver, $25 \%$ from intestine. As in table (1). Which agreed with Oghondeminus (1993) who reported, fish intestine were found to be heavy loaded with large numbers of Staphylococcus species. And disagreed with Udeze et al. (2012) who found that Staphylococcus aureus present in skin and absent in their intestine of Cat fishes samples. These results go in parallel with Haifaa (2014) and Noha (2015), who isolated Staphylococcus aureus from Skin, gills, liver, and intestine of infected Cat fishes.

The skin part of fish was exhibit large number of bacteria and this is because the skin of fish is usually in direct contact with water. These results agreed with Ali and Hamza (2004) who recorded that, sixty hand swabs from fish sellers $(35 \%)$ gave positive results for Staphylococcus aureus, fourty house wives hand swabs, $(37.5 \%)$ gave positive for Staphylococcus aureus, this mean that spoilage bacteria penetrate only slowly from the skin and the gut, although when spoilage is well advanced their presence may be all too obvious in the term of unattractive bacterial slime and repulsive odors, respectively Just below the skin. Bacterial fish diseases and infection are very common and are one of the most difficult health problems, to deal with bacteria can enter the fish body through the gills or skin or it can stay on the surface of the fish body (Douglas and Hamel 2007).

It has reported that, the gills act as the first barrier to combat infection by trapping and sloughing off pathogen, since they contain numerous mucous cells, mast cell and leukocytes. (Corrales et al., 2010, Pan et al., 2010).

In this study,430 tested samples were collected from different organs of infected cat fish. All isolates cultivated on BPA which is selective media for $S$. aureus were found black dot colony surrounded by hallow zone.

These positive colonies were tested for further biochemical characteristics, (Morphological, culture character, biochemical identification, coagulase production. mec A gen to determine methicillin resistant S.aureus (MRSA) by PCR and determine antibiotic inhibiting gen. These positive colonies were Gram +ve cocci arranged in cluster, to produce bubbles from $\mathrm{H} 2 \mathrm{O} 2$ due to production of $\mathrm{O} 2$ by the action of catalase enzyme produced by them. When urea hydrolysis test was performed with these isolates, they were found to form red to pink 
colonies. It may be due to liberation of ammonia, the product of urea hydrolysis by the enzyme urease secreted from their cell wall. Production of coagulase is an important phenotypic feature used worldwide to identify S.aureus reported by Da Silva and Da Silva (2005) and Aslantas et al. (2007). Coagulase reacts with prothrombin in blood and causes blood clot by converting fibrinogen to fibrin. The coagulase is tightly bounded to the surface of S.aureus and coats its surface with fibrin upon contact with the blood. So the result of coagulase test confirmed that those bacterial isolates which give positive results were $S$. aureus.

In these results isolated $S$. aureus were sensitive to Amikacin, Amoxicillin, Ampicillin and Ciprofloxacin; intermediated sensitive to Erythromycin and Vancomycin while resistant to Gentamicin, Methicillin and Neomycine. These results go in parallel with Daniel et al. ( 2010) who recorded that, $S$. aureus isolated from products purchased from retail outlets were susceptibil to a range of antibiotics (Cephalothin, Clindamycin, chloramphenicol, erythromycin, gentamycin, oxacillin, penicillin $\mathrm{G}$, tetracycline, vancomycine, methicillin, ciprofloxacin and trimethoprimsulfamethoxazole ). Disagreed with Albuquerque et al. (2007) who reported that, All S. aureus isolates from fish stalls and hands, nasal, oral cavities of fish handlers of the Mucuripe Fish Market were resistant to Ampicillin and $44 \%$ were multi-drug resistant. And disagreed with Haifaa (2014) who recorded that, most species of Staphylococcus isolated from fresh water fish, isolates were resistant to Ampicillin but sensitive to Ciprofloxacin. Partial agreed with Al-Obaidy and Al-Dabahg (2011) who recorded, most species of Staphylococcus were sensitive to Ciprofloxacin.

Nucleic acid amplification by PCR has applications in many fields of biology and medicine, including the detection of viruses, bacteria and other infectious agents. In the present study, oligonucleotide primer set were synthesized which recognized sequences of the MRSA ( $m e c \mathbf{A}, c o \mathbf{A}, s p \mathbf{A})$ genes.

PCR approaches using (co $\mathbf{A}, s p \mathbf{A}$, mec A) genes targeted primers, have proved specific and combined with growth techniques may improve detection of both S.aureus and MRSA in different types of food (Alarcon et al., 2006 and Hata et al., 2006).

In the present study, mec $\mathbf{A}$ gen for characterization of Methicillin Resistant S. aureus(MRSA) were detected in re-isolated sample at $533 \mathrm{bp}$. These results agreed with Noha (2015) who detected that, mec $\mathbf{A}$ gene at 310 bp from isolates identify as $S$. aureus isolated from infected Cat fish. Zamri-Saad et al. (2010). Who mentioned the report that, first documented finding of 
presence of MRSA in an aquatic animal cage-culture tilapia (Oreochromis niloticus). Tadashi Shimamoto (2012) who isolate MRSA from retail ready-to-eat raw fish in Japan. Nevertheless, antibiotic-resistant S.aureus has been isolated from cases of fish handlers disease, therefore, the issue of preventing antibioticresisrant S.aureus, including MRSA suggests regular inspection of Tilapia and perhaps other fish at points of sale is necessary (Albuquerque et al., 2007). But disagreed with Daniel VázquezSánchez et al. (2010) who reported that, no MRSA was isolated from fishery products and no isolate carried the mec A gene, though intermediate resistance to methicillin was detected in all isolates from fishery products marketed in Galicia (Northwest Spain).

In the present study, gave PCR product with specific band at 139 bp which confirmed the presence of erm A gen in 5 isolates, at $174 \mathrm{bp}$ confirmed the presence of aac (6)aph (2) genes in 3 isolates, at 1030 bp confirmed the presence of van $\mathbf{A}$ gen in 2 isolates. These results confirm presences of antibiotic resistance genes to erythromycin, vancomycin and gentamycin. These results disagreed with Tadashi Shimamoto (2012) who recorded that, Antibiotic resistance genes that conferm resistance to aminoglycosides, tetracyclines, $\beta$ lactams, macrolides, lincosamides and streptogramin B (MLS(B)) antibiotics were detected isolated samples from retail ready-to-eat raw fish in Japan

Table(1); Total incidence of S.aureus among examined different organs and tissue of infected Cat fish;-

\begin{tabular}{|l|l|l|l|l|l|}
\hline \multirow{2}{*}{ Organ } & \multirow{2}{*}{$\begin{array}{l}\text { Total number of examined } \\
\text { sample }\end{array}$} & \multicolumn{2}{l|}{ Positive / 150 } & \multicolumn{2}{l|}{ Negative / 150 } \\
\cline { 3 - 6 } & & No. & \% & No. & $\%$ \\
\hline gills & 150 & 150 & 100 & 0 & 0 \\
\hline ulcers & 150 & 150 & 100 & 0 & 0 \\
\hline liver & 150 & 60 & 40 & 90 & 60 \\
\hline kidney & 150 & 45 & 30 & 105 & 70 \\
\hline intestine & 150 & 25 & 17 & 125 & 83 \\
\hline total & 750 & 430 & 57 & 320 & 42.6 \\
\hline
\end{tabular}


Table (2): Interpretation of antibiotic sensitivity test for S.aureus isolates .

\begin{tabular}{|c|c|c|c|c|c|c|c|}
\hline \multirow[t]{2}{*}{ Antimicrobial agent } & \multirow[t]{2}{*}{ 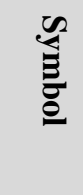 } & \multirow{2}{*}{$\begin{array}{l}\text { Disc } \\
\text { conc. }\end{array}$} & \multicolumn{3}{|c|}{$\begin{array}{l}\text { Diameter of inhibition } \\
\text { zone }(\mathrm{m} \mathbf{m})\end{array}$} & \multirow{2}{*}{ 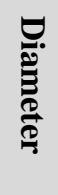 } & \multirow{2}{*}{ 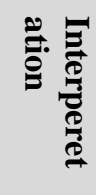 } \\
\hline & & & $\mathrm{R}$ & I & $S$ & & \\
\hline Amikacin & $\mathrm{AK}$ & $10 \mu \mathrm{g}$ & $\leq 11$ & $12-13$ & $\geq 14$ & 19 & $\mathbf{S}$ \\
\hline Amoxicillin & $\mathrm{Ax}$ & $25 \mu \mathrm{g}$ & $\leq 19$ & & $\geq 20$ & 22 & $\mathbf{S}$ \\
\hline Ampicillin & $\mathrm{Am}$ & $10 \mu \mathrm{g}$ & $\leq 11$ & $12-14$ & $\geq 15$ & 21 & $\mathbf{S}$ \\
\hline Ciprofloxacin & CIP & $5 \mu \mathrm{g}$ & $\leq 15$ & $16-20$ & $\geq 21$ & 22 & S \\
\hline Erythromycin & $\mathrm{E}$ & $15 \mu \mathrm{g}$ & $\leq 13$ & $14-22$ & $\geq 23$ & 18 & I \\
\hline Gentamicin & GM & $10 \mu \mathrm{g}$ & $\leq 12$ & $13-14$ & $\geq 15$ & 12 & $\mathbf{R}$ \\
\hline Methicillin & $\mathrm{ME}$ & $5 \mu \mathrm{g}$ & $\leq 9$ & $10-13$ & $\geq 14$ & 8 & $\mathbf{R}$ \\
\hline Neomycin & $\mathrm{N}$ & $30 \mu \mathrm{g}$ & $\leq 12$ & $13-16$ & $\geq 17$ & 10 & $\mathbf{R}$ \\
\hline Vancomycin & VA & $30 \mu \mathrm{g}$ & $\leq 9$ & $10-11$ & $\geq 12$ & 10 & I \\
\hline
\end{tabular}
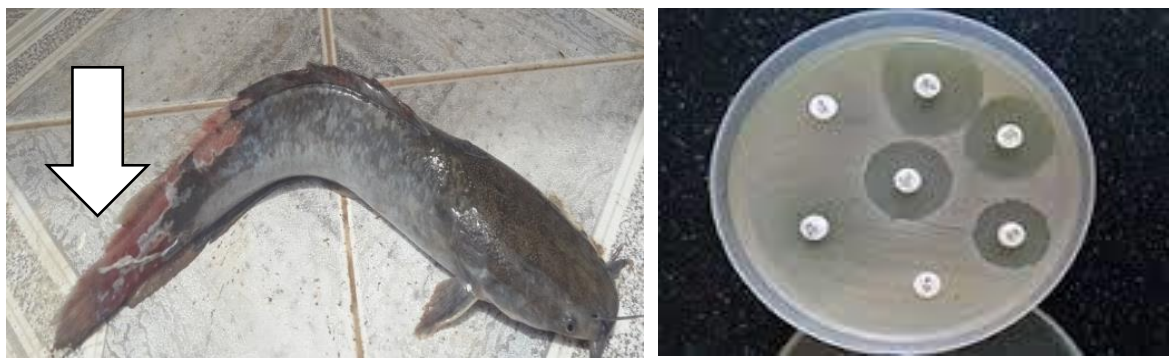

Fig .(1): Diseased Cat fish showing skin lesion at tail

Fig. (2): S. aureus disc diffusion sensitivity pattern showing sensitive to Amikacin, Amoxicillin, Ampicillin and Ciprofloxacin while resistant to Gentamicin, Methicillin and Neomycine

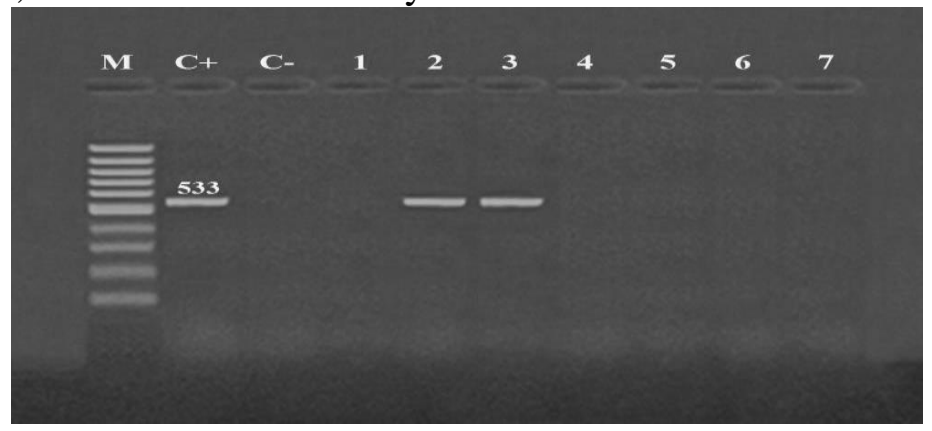

Fig. (3):Agarose gel electrophoresis of PCR amplification products of mecA gene for characterization of Methicillin Resistant Staphylococcusaureus (MRSA).

Lane M :100 bp ladder as molecular size DNA marker.

Lane C+: Control positive $S$. aureus for mec A gene.

Lane C- : Control negative.

Lanes 2 and 3: Positive $S$. aureus strains for mec A gene.

Lanes 1, 4, 5, 6 \& 7: Negative $S$. aureus strains for mec A gene. 


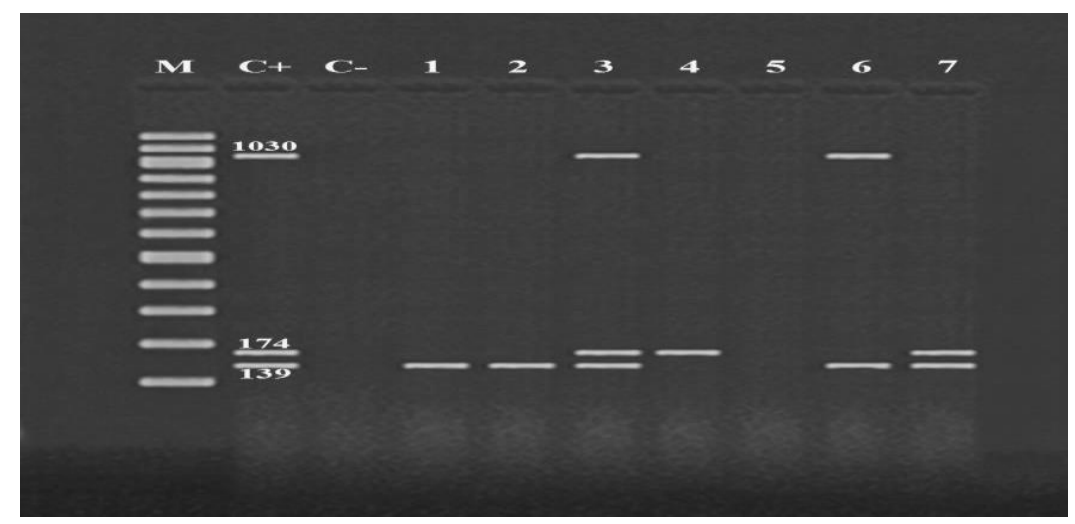

Fig. (4):Agarose gel electrophoresis of multiplex PCR of erm A (139 bp), aac (6)-aph (2) (174 bp) and van $\mathrm{A}(1030 \mathrm{bp})$ as antibiotic resistance genes of $S$. aureus.

Lane M : 100 bp ladder as molecular size DNA marker.

Lane C+: Control positive for erm A, aac (6)-aph (2) and van A genes.

Lane C- : Control negative.

Lanes 1 and 2: Positive S.aureus strains for erm A gene.

Lane 3 : Positive S.aureus strain for erm A, aac (6)-aph (2) and van A genes.

Lane 4 : Positive S.aureus strain for aac (6)-aph (2) gene.

Lane 6 : Positive S.aureus strain for erm A and van A genes.

Lane 7 : Positive S.aureus strain for erm A and aac (6)-aph (2) genes.

Lane 5 : Negative S.aureus strain for erm A, aac (6)-aph (2)and van A genes.

\section{References}

Alarcon B, Vicedo. B., Aznar R. (2006). PCR-based producers for detection and quantification of S.aureusand their application in food.J. Appl. Microbiol., 100(2):352-364.

Albuquerque, W.F., Macrae, A. Sousa, O.V., Vierira, G.H.F. , Vieira, R.H.F.(2007). Multiple drug resistant Staphylococcus aureusstrain isolated from a fish market and from fish handlers. Brazilian Journal of Microbiology. 38: $131-134$.
Ali, H.H. (2014). Isolation and identification of staphylococcus bacteria from fish of fresh water and its antibiotics sensitivity in Mosul city. Bas. J. Vet.Res., 1(1): 3342.

Ali, M.A., Hamza, M.I.E. (2004). Prevalence of seafood borne pathogens in shellfish at retail level. 1st Ann. Confr., FVM., Moshtohor. Pp.1 15. Andrew, A.E. 2001. Fish processing technology. University of Ilorin press, Nigeria. Pp. 78.

Al-Obaidy, N.K. Al - Dabahg, S.Y. (2011). Isolated and identification of pathogenic bacteria 
from intestine of Cyprinuscapriofish from Tigris river in Mosul city. J. Edu. and Sci. 3 (25): (in Arabic).

Aslantas, O., Demir, Turutoglu, H., Cantekin, Z., Ergun, Y., and Dogruer, G (2007). Coagulase gene polymorphism of S.aureus isolated from subclinical bovine mastitis. Turk J Vet AnimSci 31(4):253-257.

Athanassopoulou, F., Prapas, T. and Rodger, H. (1999). Diseases of Cuvier, PuntazzoPuntazzo $\mathrm{L}$ in marine aquaculture systems in Greece. fish Dis, 22:215-218.

Austin, B. and Austin, D. A., (2007):- Bacterial Fish Pathogens of Farmed and Wild Fish Third (Revised) Edition. Praxis Publishing Chichester, U.K., 457p.

BAM (Bacteriological Analytical Manual), (2001).Staphylococcus January Chap. aureus, http:www.fda.gov/food/foodscience research/

laboratorymethods/ucm071 429 . htm

Beleneva, I.A., (2011). Incidence and characteristics of S.aureus and Listeria monocytogenes from the Japan and South China seas. Marine pollution Bulletin 62,382-387.

Bujjamma and Padmavath (2015):- Prevalence of Staphylococcus aureusin Fish Samples of Local Domestic Fish Market. Int. J. Curr. Microb. App. Sci. 4(5):427-433.

Corrales J., Mulero I.,Mulero V., Noga E.J. (2010). Detection of antimicrobial peptides related to piscidin 4 in important aquacultured fish. Dev Comp Immunol:34:331343.

Da Silva, E.R. and Da Silva, N.(2005). Coagulase gen typing of S.aureus isolated from cows with mastitis in Southeastern Brazil. Can J Vet Res 69:260-264.

Daniel Vázquez-Sánchez, Marta López-Cabo, Paula Saá-Ibusquiza and Juan José Rodríguez(2010).Incidence

and characterization of Staphylococcus aureus in fishery products marketed in Galicia (Northwest Spain). Seafood Microbiology and Technology Section, Marine Research Institute, Spanish National 6 Research Council (CSIC), Eduardo Cabello 6, 36208, Vigo (Spain).

Douglas and Du Hamel.(2007):Identifying-fish-diseases. Journal of Appl. Aquaculture. 2(1)1-9.

EFSA, European Food Safety Authority, (2010). The Community Summary Report on Trends and Sources of Zoonoses, Zoonotic Agent and Food-borne outbreaks in the European Union in 2008.EFSA.j.,8(1):1496.

Eklund, M.W., M.E. Peterson, F.T. Poysky, R.N. Paranjpye, G.A.Pelroy (2004): Control of bacterial pathogens during processing of cold-smoked and dried salmon strips. J. Food Protect., 67: 347-351.

El-olemy, G.M., Lobna, M.A.S., Nashwa, O. Khalifa, Mona, S., Abdel Wahab, (2014). Detection of 
some bacterial zoonosis in market fish in Qalyoubia province and their control. BenhaVeter. Med. J., 26(2): 1261136.

Haifaa Hussein Ali (2014):Isolation and identification of Staphylococcus bacteria from fish of fresh water and its antibiotics sensitivity in Mousl city. Bas.J.Vet.Res.1,(1).

Hata, E., Katsuda, Kobayashi, H., Ogawa, T., Endo, T., Eguchi, M.(2006). Characteristics and epidemiologic genotyping of S.aureus isolates from bovine mastitis milk in Hokkaido, Japan.J. Vet. Med. Sci. 68, 165-170.

Herrero, M.M.H., R.X.R. Sagues, j.J.RGerez and M.T.M. Ventura (1999).Halotolerant and halophilic histamine forming bacteria isolated during the ripening of salted anchovies. J. food protection, 62(5): 509-514.

Lotfi, Z.Z., Shehata, A.A., Mohamoud, M.S., Farid, A.F., Nada, S.M. (1972). Bacterial flora in Nile and sea fishes in Egypt. Presented to the $10^{\text {th }}$ Arab Vet. Cong. $589-600$.

Narges Ahani, Majid AlipourEskandani (2013):- Detection of Enterotoxigenic Staphylococcus aureus in Schizothorax zarudnyi Using PCR Method.Zahedan J. Res. Med. Sci. 16(4): 29-31

NCCLS (1997)National Committee for Clinical Laboratory Standard staph. Methods for dilution antimicrobial susceptibility tests for bacteria that grows aerobically. Approved Stundards, M7-A4.
Noga, E., (1996):- Fish Diseases : Diagnosis and trearment. S T. Louis (Ed.) pp. 139-162. North Carolina State university, mosby, Missouri.

Noha Mohamed (2015). The inhibitory effect of normal hony on chromosome and plasmid encoded genes of multi drug resistance S.aureus isolated from different sources. Ph. D. Degree in Veterinary Medical Science (Suez Canal Univeristy)

Ogbondeminus, F.S. (1993):- The occurance and distribution of enteric bacteria in fish of tropical aquaculture ponds in Nigeria. J. of Aqua. In tropics, 8(1): 66.

Pan S., Tang J., Gu X (2010). Isolation and characterization of a novel fucose-bindind Lectin from the gill of bighead carp (Aristichthys nobilis). Vet Immunol Immunopathol: 133:154-164.

Perez, E.; Claverie, M.; Villar, J. and Alvarez, M. (2001): Multiplex PCR for simultaneous identification of Staphylococcus aureus and detection of methicillin and mupirocin resistance. J. Clin. Microbiol., 39 (11): 4037- 4041.

Popovich, K.J., Hota, B., andWeinstein, R.A., (2007). Treatment of community-associated methicillin-resistant S.aureus. Current Infectious Disease Reports 9, 398-407.

Pournajaf, A.; Ardebili, A.; Goudarzi, L.; Khodabandeh, M.; Narimani, T. and Abbaszadeh, $H$. (2014):PCR-based identification of methicillin-resistant

Staphylococcus aureus strains and 
their antibiotic resistance profiles.Asian Pacific J. Tropical Biomed., 4 (1): 293-297.

Quinn, P.J, Carter, M.E., Makrkey, B.K.and Carter, G.R. (1994):- Clinical veterinary microbiology. Mosby year book Europ Limited Lynton House, London. 109-126

Ribeiro, A., Coronado, A.Z., Silva- Carvalho, M.C., FerreiraCarvalho, B.T., Dias, C., Rozenbaum, R., Del-Peloso, P.F., Ferreira-Leite, C.C., Teixeira, L.A., and Sa-Figueiredo, A.M.(2007). Detection and characterization of international community-acquired infections by methicillin-resistantS.aureusclones in Rio de Janeiro and Porto Alegre cities causing both community and hospital associated diseases. Diagnositic Microbiology and Infectious Diseases 59, 339-345.

Roberts, R.J. (2001). Fish pathology $3{ }^{\mathrm{rd}}$ Ed WB Saunders Elsevier science limited, pp. 297 366 .

Shah, D., Shringi, S., Besser, T. and Call, D. (2009): Molecular detection of foodborne pathogens, Boca Raton: CRCPress, In Liu, D. (Ed). Taylor \& Francis group, Florida, USA, Pp. 369-389.

Simon, S.S., Sanjeev, S. (2007). Prevalence of enterotoxigenic Staphylococcusaureusin fishery products and fish processing factory workers. FoodControl, 18(12): 15651568.
Stankovic, C., Mahajan, P.V., and Asmar, B.I. (2007). Methicillinresistant S.aureus as a cause of community-acquired pneumonia. Current Infectious Disease Reports 9, 223-227

Tadashi Shimamoto, Ahmed M.Hammad, Wataru Watanabe, Tomoko Fujii, (2012). Occurrence and characteristics of methicillinresistant and susceptible S.aureus and methicillin-resistant- coagulasenegative Staphylococci from Japanese retail ready to eat raw fish. International Journal of food Microbiology 156, 286-289

Udeze A.O., Talatu M., Ezediokpu M.N., Nwanze J.C., Onoh C., Okonko I.O. (2012). The effect of Klebsiella pnemoniae on Cat fish. Researcher 4(4):51-59.

Vieira R.H.S.F., Rodrigues D.P., Gocalves F.A., Menezes F.G.R., Aragao J.S., Sousa O.V. (2001): Microbicidal effect of medicinal plant extracts (Psidium guajava Linn. and Carica papaya Linn.) upon bacteria isolated from fish muscle and known to induce diarrhea in children. Rev. Inst. Med. Trop. S. Paulo, 43, 145-148

Zamri-saad M,Atyah M.A.S, SitiZahrah. A (2010). First report of methicillin-resistant S.aureus from cage-cultured tilapia (Oreochromis niloticus). Vet.Microbiol. 144:502504 


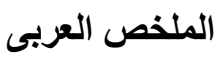

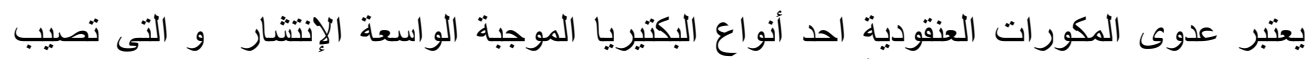

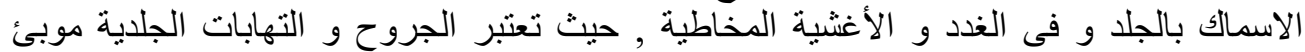

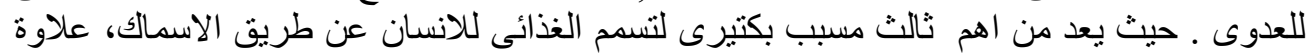

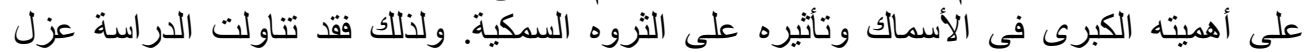

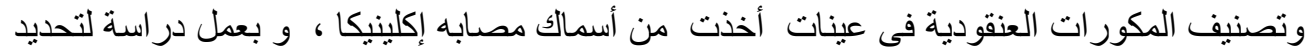

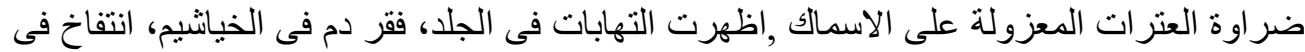

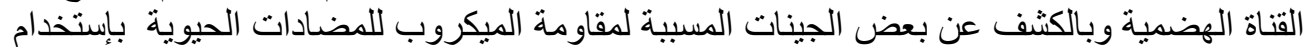

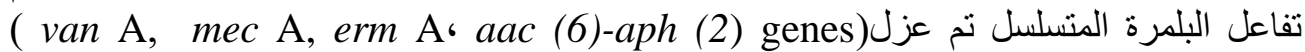

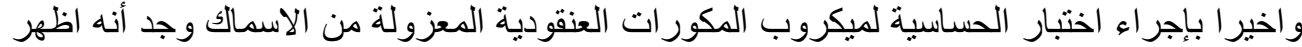
حساسيه لجميع المضادات الحيوية المستخدمة. ماعدا المثيتلين و النيو ميسين و الجنتاميسين. 